\title{
『金剛句心䯣集難語釈』の作者の問題と 「時輪教」の成立時期
}

静 春 樹

カーラチャクラ (Kālacakra, 以下, 時輪) 学派の成立と流布はインド後期仏教史 における一大事件であったと思われる。『真実摂経』（『初会金剛頂経』）の成立に よって確立したインド仏教金剛乗は,「最勝の大乗」と自らを位置づけ, 経部大乗 (波羅蜜乗) からの優位を主張する。この当初の段階は仏典であるタントラとして は瑜伽階梯に位置づけられる.「タントラ五分類法」では, その直接の延長線上に 来るのが大瑜伽タントラ (yogottaratantra, 最上瑜伽タントラ・父タントラ) であり, そ の根本聖典が『秘密集会タントラ』である，他方，母神崇帱の強い影響下に成立 したのが瑜伽女タントラ (母タントラ) 経典群である. そこで仏教徒たちが大瑜伽 タントラと瑜伽女タントラの統一的理解, 具体的にはすでに確立していた所作 · 行 ・瑜伽・大瑜伽の四階梯からなる真言理趣の体系への瑜伽女タントラの取り込 みに腐心したことは想像に難くない. 仏教徒の中には, 最上瑜伽タントラまでは 容認できるが, 瑜伽女タントラは外教徒の説であるとする至極妥当な意見もあり, それに対してヴィクラマシーラ僧院の真言阿闍梨であった Bhavyakinti は「〔大] 瑜伽タントラが仏説であれば瑜伽女タントラも仏説, 瑜伽女タントラが魔説であ れば〔大〕瑜伽タントラも魔説と了解すべきである」という趣旨の反駁を行って いる ${ }^{1)}$. この父タントラと母タントラの統合的理解は時輪のグループにとっても 継続した大きな課題であった. 時輪の唱導者たちは瑜伽女タントラの理論と実践 について多岐にわたるテーマで声高に論じたこともあって，彼らに対する批判的 な意見が仏教徒の中にあったことが Abhayākaragupta (*1064-1125) 作 Āmnāyamañjarī に出る文言から理解される。 それは，時輪学派を論難する者たちの意見として出 されている。

時輪とそれに関連する諸典籍において, 三乗と相違する多くのシステムが作られたので あり，その典籍の作者（de’i gzhung byed pa）であるヤシャ王（〔Rigs ldan〕Grags pa）や 
プンダリーカやヴァジラガルバやヴァジラパーニの名前をもつその者たちは何ら菩薩で はないと多くを知る者たちは語るのである ${ }^{2)}$.

引用者が論難者の見解だと断っているとしても, タントラの編纂者を名指しで 明かすことは禁じ手である．さらに，プンダリーカ作『無垢光』（Vimalaprabhā, 以 下, VP), ヴァジラパーニ作 Laghutantrațīkā（以下, LTṬ), ヴァジラガルバ作 Hevajratantrapiṇ̣̄ārthațīkā は「菩薩の三部作」と呼ばれる時輪学派の規範的な典籍 である．故にこの論難者は時輪学派を全面的に否定していることになる.

これまでなされてきた時輪学派の研究は, 主に「インド・チベット密教」とい う創作された分析概念が使用されてきたことから，チベット仏教によるインド仏 教受容・継承関係からだけではインド金剛乗の独自相の析出が死角となり，また プトゥン（Bu ston Rin chen grub, 1290-1364）に代表されるチベット仏教の時輪解釈に 過剰に影響されていることも否めない.

本稿では『金剛句心䯣集難語橎』（Vajrapādasārasaṃgrahapañjikā, 以下，『難語橎』）の 作者の問題を取り上げ，時輪典籍群が金剛乗にもたらした全体像に迫るための準 備としたい.『難語釈』は,『プトゥン仏教史目録部』では『大註』の題名でナー ローパ（Nāropa）の作とされている ${ }^{3)}$ ．北京版大蔵経では本文冒頭の題名表記に先 立って，「『吉祥金剛句心髄集』と名づけるもの，ナーローパーダがお作りになっ たものである」4）との付記が見られる.

これは同書をナーローパ作とするプトゥンの見解を反映したものであろう。こ の付記はデルゲ版大蔵経には見られない.しかし, 北京版大蔵経の付記をそのま ま受け取って，この典籍をナーローパの著作とすることには疑問がある。まず， 同書の本文と奥書に出る記述では，著者は dpal kha che chen po shā kya’i dge slong sNyan grags bzang po「吉祥なる偉大なカシミールの釈子比丘 sNyan grags bzang po (*Yaśakīrtibhadra)」と出ており，ナーローパではない。同書がナーローパ作であれ ば, sNyan grags bzang po とナーローパは同一人物となる。 ところが, 後期インド 仏教史と「聖者伝説」に名を残すナーローパが sNyan grags bzang po なる別名を もっていたことを筆者は知らない.

そこで，まず時輪の時代的枠組みを明らかにするためと，一度広まった謬説が しぶとく残る例としてナーローパの没年を取り上げる．インド仏教史の時代確定 にあたって，基準となる絶対年代として大きく役立つ事件が西チベットのグゲ王 室によるアティシャ（Dīpaṃkaraśrīiñ̄āna, 982-1054）のチベット招請である。伝記作 者がアティシャに 19 年間も師事したナクツオ訳経師（Nag tsho Tshul khrims rgyal ba, 
1011-1064）に直に聴聞したところに拠るといわれる『アティシャ伝』から引用する.

その〔アティシャのチベットへの出発が近づいた〕時に，尊者ナーロー・パンチェンが ヴィクラマシーラ僧院へやって来たので, 出家の全員が歓迎して, アティシャも右手で 支え，Jñānaśrīmati が左手で支えて輿に招いたのである，その時に，尊者ナーローパが， 「尊者ディーパンカラよ, 今日では, 仏の教説の上首は汝である」と仏の教説を引き渡し たところ，尊者アティシャが「汝は太陽と月の如くに住しておられるが，拙僧は蛍のほ どにも世間を照らすことが出来ましょうか」とお尋ねになったので,〔ナーローパが〕「私 はもう先は長くはないので, 仏の教説の上首は汝である」と仰った. そして, そこで二 十日ばかり滞在なされて, 尊者（アティシャ）とナーローパの二人はお互いに法を尋ね 合うことはなかったと〔訳経師〕ナクツォが仰った．（中略）「それから, 吉祥ナーロー パは南へ赴かれて, 二十日ほどして逝去され〔たのである.〕遺骨のかけらをアティシャ がお迎えして，〔ナーローパは〕今日， sNye thangの霊塔の内に住しておられる」と〔ナ クツオ」が仰った5).

この引用から，アティシャがチベットへ旅立つ 1040 年にナーローパは没してい ることが明らかとなる ${ }^{6)}$. 信憑性の高い伝記の記述があるにも拘わらず, マルパ の伝記に依って, 彼の生没年に関して現在も一部で, 生年を 1016 年, 没年を 1100 年とする説が行なわれていることは学問的に理解しがたい. この生没年では『青冊 史』（以下，BA）を筆頭とするチベット歴史書が大枠で一致する「ヴィクラマシーラ 僧院北門の守護者ナーローパ」の記載とは全くの齟踾をきたしてしまう.

『難語釈』の思想的立場は冒頭の記述から明白である.

まずここでは, 『吉祥本初仏タントラ』の最勝なる次第どおりに，〔また〕吉祥なるヴァ ジラガルバたちと吉祥なるヴァジラパーニの経典と他の夕ントラについての余すところ なき善説から引用して, 様々な教誡の中で説かれる印契と曼茶羅とマントラと護摩と広 大羯磨などの広大と甚深を怖れるが故に, 極めて簡潔に要約して, 『吉祥へーヴァジラ』 の決定された語句の幾ばくかを妙勝なるグルが相承した口伝次第を得たカシミールの大 士が自分の心覚えのためと弟子たちの理解のために正しく緾めて記述しょう7).

『難語釈』の教証として, 経部大乗からは圧倒的に『八千頌般若経』, 金剛大乗 では無上瑜伽部を中心にして実に多くのタントラが挙げられている. しかし，作 者の明言どおり，根本的に依って立つ典籍は『本初仏』とその註釈書 VP および 『文殊真実名義経』（Nāmasamgīti）である。さらに引用文がヴァジラガルバとヴァ ジラパーニの名を挙げ, とくに後者の手になるLTT を重用していることからも分 かるとおり, 同書はカーラチャクラ学説流布の目的で権威ある『ヘーヴァジラタ ントラ』を使用した論書であると考えられよう。 
つぎに，『難語勫』が重要な箇所で何回も引用するヴァジラパーニ ${ }^{8)}$ の問題を 取り上げる，BA では，彼は「丁巳」（ひのとみ，1017）年生まれとされる ${ }^{9)}$ 。この ヴァジラパーニが『難語勫』に引用されるLTṬ の作者と同一人物であるとすれ ば,さらに，プトゥンが述べるように，『難語釈』の編纂者がナーローパであると すれば, ナーローパの没年（1040）に彼は二十三歳であった計算になる。当然, LTT はそれ以前の著作となる。 ところで，アティシャ招請の目的でヴィクラマシー ラ僧院に滞在していたナクツォは, アティシャの僧院不在の機会に, 有名なナー ローパを一目見ようと Phullahariへ出かけている，そこで群衆に揉まれたナクツオ は肥満した身体で輿に乗り担がれていくナーローパを一瞬だけ見ることができた という。彼が目にしたナーローパの姿は，地方有力者の帰依を受け，名声を博し て最晚年を迎えた在俗瑜伽行者（siddha）のそれであった。そこから，多数の典籍 を駆使して『難語勫』を著述する学匠の姿は想像できない10). 同書がナーローパ の著作であるとしても，それはかなり以前の作であるとするのが自然であろう. そうだとすれば, LTṬ はヴァジラパーニの十代後半の著作ということになろう．

「時輪教」成立年代について我が国では, 羽田野伯奠説 ${ }^{11)}$ が現在も影響力をも つ.一方，LTṬのサンスクリット校訂本を出版した Claudio Cicuzza は，それとは 全く異なる説を出している.

『本初仏』のテキストは, LTṬ が編纂された時期（おそらく十世紀の終わり頃）には，そ のすぐ後にVP が編纂される時にそうであったと思われる形で出来てはいなかった．そも そも『本初仏』が完成した形で存在したかどうかは分からない. テキストは本来 Sekoddeśa のような旧来の核となる部分から成っていたと思われる。 それがいろいろな瑜伽行者 （yogin）たちに認められ引用されている内に, 結果として, 彼らはテキストの別な箇所に 詳説されている核となる部分に表出された教義を信奉することになった ${ }^{12)}$.

ヴァジラパーニは，このタントラのインドにおける当初の舞台を飾る人物である。その 時期に一群の瑜伽行者（その最も有名な人物が Śrīyaśas と Pundalalīka）が協業して時輪の 最初のシリーズを詳論する。おそらく十世紀後半のことであろう。ヴァジラパーニ，つ まりこの名前をもつ一人の阿闍梨はその学派のメンバーであり, その教義を信奉し, 詳 論し，規範となる著作の編纂を始めた最初の瑜伽行者であった ${ }^{13)}$.

Cicuzza は, BA「時輪の章」が「サンヴァラの註橎書」（LTT ）の作者として一 度だけ名前を出すヴァジラパーニ ${ }^{14)}$ と「マハームドラーの章」が何度も名を挙げ るヴァジラパーニ 15) (生年丁巳)，そしてチベット人訳経師たちと翻訳作業に携わっ たヴァジラパーニとが同一人物であるとする。他方で，時輪学説の登場が 967 年 
から 1026 年の間であり，典籍の引用・被引用関係に基づく推定から LTT が最初 期の時輪学説に属するとすれば, LTṬ の作者の生年は丁巳（1017）ではありえな いと述べる。ここでもチベット歴史書の信憑性が問題となる. Cicuzza は, 「ヴァ ジラパーニ複数説」は出していない. しかし BA の記述を認めた上で, LTT が最 初期の時輪学説であるとすれば，そこから導き出せるのは「ヴァジラパーニ複数 説」しかない，他方で，「ヴァジラパーニ複数説」を提起すれば，『難語釈』の 「ナーローパ作者説」の可能性も残り得る. ともあれ, 同書の作者については奥書 が sNyan grags bzang pos と述べていることに留意したい.

「原時輪タントラ」テキストの問題については，『難語釈』の引用は示唆的であ る. 同書は引用に際して, dpal dang po’i gsang rgyas（『吉祥本初仏』*śrī-Ādibuddha） と dpal mchog gi dang po’i sangs rgyas（stong phrag bcu gnyis pa）(『[一万二千頌から成る] 吉祥最勝本初仏』*śrī-Paramādibuddha）を明確に区別している.

Cicuzza が論じるとおりにヴァジラパーニが時輪学説の最初期の人物だとすれ ば, VP にも先行する LTT の内容から, まさしく同書が在俗瑜伽行者と僧院の比 丘からなる金剛乗の世界に「比丘至上主義」とある種の「能力主義」の統合シス テムを持ち込んだおそらく最初の典籍となる。また聚輪（ganacakra）の姉妹儀礼で ある勇者の饗宴 (vīrabhojya) の登場もヴァジラパーニと不可分の関係をもつこと になる. Cicuzza が「一群の瑜伽行者」としているヴァジラパーニを始めとする時 輪学説の最初期唱導者たちの具体相の解明が今後の課題である.

1) Toh 1405, Ma. 19a3-7. 2) Toh 1198, Cha. 198b7-199a2. 3) 西岡 (1983,91). Nā ro pas mdzad pa'i 'Grel chen dPal Chos bzang gi 'gyur. $\quad 4$ ) Ota 2316, Tsha. 69a2. dpal kye'i rdo rje tshig gi snying po bsdus pa zhes bya Nā ro zhabs kyis mdzad pa bzhugs so //.

5）『アティシャ伝』(1979, 172 (231)). 6) 川越（2001, 292, fn. 96). 7) Toh 1186, Ga. 58b7-59a2. 8）チベットの歴史書では, タントラの行法をしたという理由 でヴィクラマシーラ僧院から追放されたという逸話をもつマイトリパ（別名 Advayavajra） の四大弟子の一人とされる.

9) BA, Da. 2b2-6, Roerich $(1976,842-843)$.

10）『インド上師伝』277-278, Davidson (2002,317). 11) 羽田野 $(1987,19,32)$ は, 主にチベット語資料に依って「時輪教」成立と流布の複雑な伝承の解明に努めているが, 結論となる次の時代設定は再検討の必要がある。「時輪の成立年代を学者の承認せる 965 年よりかなり後に設定しなければならぬであろう。（略）ゆえに，右の年代を西暦に換算 すれば，時輪成立の年代は，その上限を 1027 年とする 60 年の期間としなければならぬ.」 「(略) マガダを中心とする大小時足の時輪活動は, 早くも 1040 年をさかのぼりえず，時 輪教の一般的流布は, 1000 年代の中葉から 1100 年代のはじめにかけて果たされたという
ことである.」
12) Cicuzza $(2001,13)$.
13) Cicuzza (2001, 25-26).
14) BA, 
Tha. 40b5, Roerich $(1976,838)$.

15) BA, Da. 2b3-12b7, Roerich $(1976,842-866)$.

〈一次文献, 略号〉

『アティシャ伝』rNam thar rgyas pa. 2. Teil. Ed. Helmut Eimer. Wiesbaden: Otto Harrassowitz, 1979.

『インド上師伝』Bla ma rgya gar ba’i lo rgyus. Grags pa rgyal mtshan. SKKB, vol. 3, no. 11. 1968.

『難語釈』Vajrapādasārasamgrahapañjikā. Toh 1186, Ota 2316.

BA The Blue Annals: Completed in A.D. 1478 by Hgos-Lotsawa Gzhon-nu dpal. Reproduced by Lokesh Chandra from the collection of Raghu Vira. ŚPS, vol. 212. 1974.

VP Vimalaprabhā. Ed. Vrajavallabh Dwivedi and Shrikant Bahulkar. RBTS 12. 1986. Toh 1347.

LTṬ The Laghutantrațīkā by Vajrapāni. Ed. Claudio Cicuzza. Serie Orientale Roma, vol. 86.

Roma: Istituto Italiano per L'africa e L'oriente, 2001.

RBTS Rare Buddhist Text Series. Sarnath: Central Institute of Higher Tibetan Studies.

SKKB The Complete Works of the Great Masters: The Sa sKya Sect of the Tibetan Buddhism.

Tokyo: Toyo Bunko.

ŚPS Śata-Pițaka Series. New Delhi: International Academy of Indian Culture.

\section{〈二次文献〉}

川越英真 2001「Nag tsho Lo tsā ba について (2)」『東北福祉大学研究紀要』26: 275-295.

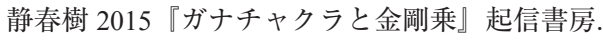

田中公明 1994 『超密教時輪タントラ』東方出版.

西岡祖秀 1983 「プトゥン仏教史』目録部索引 III」『東京大学文学部文化交流研究施設研 究紀要』6: 47-201.

羽田野伯鄭 1987 「時輪タントラの成立に関する基本的課題」『チベット・インド学集成』 第 3 巻, 法蔵館, 10-35.

Claudio, Cicuzza. 2001. The Laghutantrațīka by Vajrapāṇi. Serie Orientale Roma, vol. 86. Roma: Istituto per L'africa e L'oriente.

Davidson, Ronald M. 2002. Indian Esoteric Buddhism. New York: Columbia University Press.

Roerich, George, trans. 1976. The Blue Annals. Delhi: Motilal Banarsidass.

Shizuka Haruki. 2015. "Expulsion of Maitri-pa from the Monastery and Atiśa's Participation." Indogaku Bukkyōgaku kenkyū 印度学仏教学研究 63 (3): 1315-1321.

〈キーワード〉『金剛句心髄集難語釈』, カーラチャクラ, ナーローパ, ヴァジラパーニ, 勇者の饗宴 